\title{
Umpan Balik Proses Pembelajaran pada Jurusan Teknik Industri FT UMJ
}

\author{
Annisa Mulia Rani', Meri Prasetyawati² \\ Universitas Muhammadiyah Jakarta \\ Email : zc.annisa@gmail.com ${ }^{1}$ merie_jeng@yahoo.co.id ${ }^{2}$
}

\begin{abstract}
Abstrak
Perkembangan ilmu pengetahuan dan teknologi membawa perubahan disemua aspek kehidupan yang menuntut diperlukannya sumber daya manusia yang berkualitas dan unggul sehingga mampu berdaya saing tinggi. Umpan balik proses pembelajaran khususnya dosen, mahasiswa, alumni dan pengguna lulusan di jurusan teknik industri amatlah penting sehingga dapat mengetahui tentang harapan dan persepsi mereka. Oleh karena itu Jurusan Teknik Industri FT UMJ berusaha untuk memberikan pelayanan yang baik, salah satunya dengan meningkatkan kualitas proses pembelajaran sehingga mampu untuk meningkatkan daya saing dalam institusi pendidikan. Salah satu tahapan proses peningkatan adalah dengan melakukan kajian tentang proses pembelajaran melalui umpan balik dari dosen, mahasiswa, alumni, dan pengguna lulusan mengenai harapan dan persepsi mereka sehingga evaluasi dan tindak lanjut dapat segera dilakukan. Hasil rencana tindak lanjut atas umpan balik mahasiswa dalam proses pembelajaran adalah mengaktifkan dosen PA, mensosialisasikan SOP pelayanan terpadu, meningkatkan kedisiplinan jam pelayanan kepada mahasiswa, menambah jumlah beasiswa. Rencana tindak lanjut atas umpan balik dosen dalam proses pembelajaran adalah berlangganan jurnal online, menambah koleksi e-book, menambah dan memperbaiki alat pembelajaran, mengupgrade peralatan laboratorium, mengoptimalkan teknologi informasi. Rencana tindak lanjut atas umpan balik alumni adalah mensosialisasikan lapangan kerja sesuai dengan bidang teknik industri, membuat kerjasama dengan perusahaan yang dapat memberikan kesempatan lapangan kerja untuk mahasiswa. Rencana tindak lanjut atas umpan balik kompetensi lulusanmenurut pengguna adalah menyelenggarakan peningkatan integritas oleh unit AIK (Al-islam dan kemuhammadiyahan), menyelenggarakan berbagai seminar dibidang teknik industri, melakukan tes toefl di lab bahasa bagi mahasiswa baru, menggunakan ICT, proses pembelajaran menggunakan PBL (problem based learning).
\end{abstract}

Kata Kunci : Kualitas pelayanan, Umpan Balik, Rencana tindak lanjut

\section{Pendahuluan}

Dengan semakin pesatnya perkembangan ilmu pendidikan dan pengetahuan, upaya perbaikan kualitas proses pembelajaran pada Jurusan Teknik Industri di Fakultas Teknik Universitas Muhammadiyah Jakarta harus lebih ditingkatkan lagi. Tingkat kepuasan pengguna terhadap pelayanan merupakan faktor yang penting dalam mengembangkan suatu sistem penyediaan pelayanan yang tanggap terhadap kebutuhan pengguna, meminimalkan biaya dan waktu serta memaksimalkan dampak pelayanan terhadap pengguna. Perkembangan dan peningkatan jasa pelayanan pada Jurusan Industri dari tahun ke tahun semakin menjadi perhatian masyarakat. Sehingga pihak Jurusan TeknikIndustri FT UMJ harus memperhatikan kualitas pelayanan baik dari segi kinerja tenaga pengajar, pelayanan administrasi, fasilitas sarana dan prasarana yang memuaskan. Hal tersebut sebagai langkah antisipasi mengingat banyaknya perguruan tinggi lain yang lebih kompetitif, sehingga mahasiswa lebih selektif dalam memilih lembaga kependidikan.

Jurusan Teknik Industri Fakultas Teknik Universitas Muhammadiyah Jakarta (FT UMJ) berdiri pada tahun 1963 dan dalam perkembangannya, telah mendapatkan status Akreditasi B. Fakultas Teknik UMJ menyadari bahwa peningkatan kualitas sumber daya manusia merupakan suatu tugas mulia guna mencerdaskan bangsa. Dalam menghadapi era globalisasi dan meningkatnya teknologi di berbagai sektor, Fakultas Teknik UMJ mampu menghadapi tantangan tersebut dengan mencetak lulusan, dengan motto "Unggul dalam IPTEK dan Kokoh dalam IMTAQ”. Alumni Fakultas Teknik UMJ dirancang dapat bekerja mandiri dan berjiwa wirausaha sehingga dapat membuka lapangan kerja, hal ini sejalan dengan era globalisasi serta otonomi daerah.

Oleh karena itu Jurusan Teknik Industri FT UMJ berusaha untuk memberikan pelayanan 
yang baik, salah satunya dengan meningkatkan kualitas proses pembelajaran sehingga mampu untuk meningkatkan daya saing dalam institusi pendidikan. Salah satu tahapan proses peningkatan adalah dengan melakukan kajian tentang proses pembelajaran melalui umpan balik dari dosen, mahasiswa, alumni, dan pengguna lulusan mengenai harapan dan persepsi mereka sehingga evaluasi dan tindak lanjut dapat segera dilakukan.

\subsection{Kualitas.}

Menurut Deming, kualitas adalah apapun yang menjadi kebutuhan dan keinginan konsumen. Menurut Crosby kualitas adalah mempersepsikan kualitas sebagai nihil cacat, kesempurnaan dan kesesuaian terhadap persyaratan. Menurut Juran kualitas adalah mendefinisikan mutu sebagai kesesuaian terhadap spesifikasi.

\subsection{Dimensi Kualitas Jasa}

Berdasarkan perspektif kualitas, ada delapan dimensi yang dapat digunakan sebagai dasar perencanaan strategis terutama bagi perusahaan atau manufaktur yang menghasilkan barang. Kedelapan dimensi tersebut adalah sebagai berikut :

1. Performance (kinerja) yaitu karakteristik pokok dari produk inti

2. Features yaitu karakteristik pelengkap atau tambahan

3. Reliability (kehandalan) yaitu kemungkinan tingkat kegagalan pemakaian

4. Conformance (kesesuaian) yaitu sejauh mana karakteristik desain dan operasi memenuhi standar-standar yang telah ditetapkan sebelumnya.

5. Durability (daya tahan) yaitu berapa lama produk dapat terus digunakan

6. Serviceability yaitu meliputi kecepatan, kompetensi, kenyamanan, kemudahan dalam peeliharaan dan penanganan keluhan yang memuaskan

7. Estetika yaitu menyangkut corak, rasa dan daya tarik produk

8. Perceived yaitu menyangkut citra dan reputasi produk serta tanggung jawab perusahaan terhadapnya

Zeithaml, Berry dan Parasuraman telah melakukan berbagai penelitian terhadap beberapa jenis jasa dan berhasil mengidentifikasi lima dimensi karakteristik yang digunakan oleh para pelanggan dalam mengevaluasi kualitas pelayanan. Kelima dimensi karakteristik kualitas pelayanan tersebut adalah :

1. Tangibles (bukti langsung) yaitu meliputi fasilitas fisik, perlengkapan, pegawai, dan sarana komunikasi.

2. Reliability (kehandalan) yaitu kemampuan dalam memberikan pelayanan dengan segera dan memuaskan serta sesuai dengan yang telah dijanjikan.

3. Responsiveness (daya tangkap) yaitu keinginan para staf untuk membantu para pelanggan dan memberikan pelayanan dengan tanggap.

4. Assurance (jaminan) yaitu mencakup kemampuan kesopanan dan sifat dapat dipercaya yang dimiliki para staf, bebas dari bahaya, resiko ataupun keraguraguan.

Empaty yaitu meliputi kemudahan dalam melakukan hubungan, komunikasi yang baik, dan perhatian dengan tulus terhadap kebutuhan pelanggan.

\subsection{Kepuasan Pelanggan}

Kepuasan pelanggan adalah tingkat perasaan seseorang setelah membandingkan kinerja/hasil yang dirasakannya dengan harapannya. Jadi tingkat kepuasan merupakan fungsi dan perbedaan antara kinerja yang dirasakan dengan harapan. Apabila kinerja dibawah harapan, maka pelanggan akan kecewa. Bila kinerja sesuai dengan harapan, pelanggan akan puas. Sedangkan bila kinerjanya melebihi harapan, pelanggan akan sangat puas. Harapan pelanggan dapat dibentuk oleh pengalaman masa lampau, komentar dan kerabatnya serta janji dan informasi pemasar dan saingannya. Pelanggan yang puas akan setia lebih lama, kurang sensitive terhadap harga dan memberi komentar yang baik tentang perusahaan.

\subsubsection{Jenis-jenis Pelanggan}

Pelanggan adalah semua orang yang menuntut untuk memenuhi suatu standar kualitas tertentu, dan karena itu akan memberikan pengaruh pada performansi perusahaan. Pada dasarnya dikenal 3 macam pelanggan dalam sistem kualitas modern yaitu (Gasperrsz, Vincent, Manajemen Kualitas)

a. Pelanggan internal (internal customer) merupakan orang yang berada dalam perusahaan dan memiliki pengaruh pada performansi pekerja atau perusahaan.

b. Pelanggan antara (intermediate customer) mereka yang bertindak atau berperan sebagai 
perantara, bukan sebagai pemakai akhir produk itu.

c. Pelanggan eksternal (eksternal customer) merupakan pembeli atau pemakai akhir produk itu, yang sering disebut sebagai pelanggan nyata. Pelanggan eksternal merupakan orang yang membayar untuk menggunakan produk yang dihasilkan itu.

\subsubsection{Teknik Pengukuran Kepuasan Pelanggan}

Ada beberapa macam metode dalam pengukuran kepuasan pelanggan. Metode yang dapat digunakan untuk mengukur kepuasan pelanggan, metode tersebut antara lain :

1. Sistim Pengaduan

Sistim ini memberikan kesempatan kepada pelanggan untuk memberikan saran, keluhan dan bentuk ketidakpuasan lainnya dengan cara menyediakan kotak saran. Setiap saran dan keluhan yang masuk harus menjadi perhatian bagi perusahaan, sebab saran dan keluhan itu pada umumnya dilandasi oleh pengalaman mereka dan hal ini sebagai bentuk kecintaan mereka terhadap produk maupun terhadap perusahaan.

2. Survey Pelanggan

Survey pelanggan merupakan cara yang umum digunakan dalam mengukur kepuasan pelanggan misalnya, melalui surat pos, telepon, atau wawancara secara langsung.

3. Panel Pelanggan

Perusahaan mengundang pelanggan yang setia terhadap produk dan mengundang pelanggan yang telah berhenti membeli atau telah pindah menjadi pelanggan perusahaan lain. Dari pelanggan setia diperoleh informasi kepuasan yang mereka rasakan dan dari pelanggan yang telah berhenti membeli, perusahaan akan memperoleh informasi mengapa hal itu dapat terjadi. Apabila pelanggan yang berhenti membeli (customer loss rate) ini menigkat hal ini menunjukkan kegagalan perusahaan dalam memuaskan pelanggan.

Tujuan untuk melibatkan pelanggan dalam pengembangan produk dan jasa adalah agar perusahaan dapat memenuhi harapan pelanggan, bahkan jika mungkin melebihi harapan pelanggan. Persepsi yang akurat mengenai harapan pelanggan merupakan hal yang perlu, namun tidak cukup untuk memberikan kepuasan kepada pelanggan. Perusahaan harus mewujudkan harapan pelanggan kedalam desain dan standar kepuasan pelanggan. Desain dan standar kepuasan pelanggan dikembangkan atas dasar harapan konsumen.

\subsection{Teknik Pengumpulan Data \\ 1.4.1 Pengujian Validitas Instrumen}

Cara untuk menguji validitas adalah dengan menggunakan teknik analisis korelasi product moment dari pearson, rumus yang digunakan adalah sebagai berikut:

$$
\begin{aligned}
& r_{x y}=\frac{n\left(\sum x y\right)-\left(\sum x\right)\left(\sum y\right)}{\text { Dimana }: \sqrt{\left\{n \sum x^{2}-\left(\sum x\right)^{2}\right\}\left\{n \sum y^{2}-\left(\sum y\right)^{2}\right\}}} \\
& r_{x y}=\text { korelasi product moment } \\
& n=\text { jumlah responden } \\
& x=\text { skor pernyataan } \\
& y=\text { skor total seluruh pernyataan }
\end{aligned}
$$

\subsubsection{Pengujian Reliabilitas Instrumen}

Setelah pengujian validitas, selanjutnya dilakukan pengujian reliabilitas. Salah satu metode pengujian reliabilitas adalah dengan menggunakan Alpha-Cronbach. Standar yang digunakan dalam menentukan reliabel atau tidaknya suatu instrument penelitian umumnya adalah perbandingan antara nilai $r$ hitung dengan nilai $r$ tabel pada tingkat signifikasi 5\%. Apabila dilakukan pengujian reliabilitas dengan metode Alpha-Cronbach, maka nilai $\mathrm{r}$ hitung diwakili oleh nilai Alpha. Apabila Alphs hitung lebih besar daripada $r$ tabel dan Alpha hitung bernilai positif, maka suatu instrument penelitian dapat disebut reliabel.

\section{Methodologi}

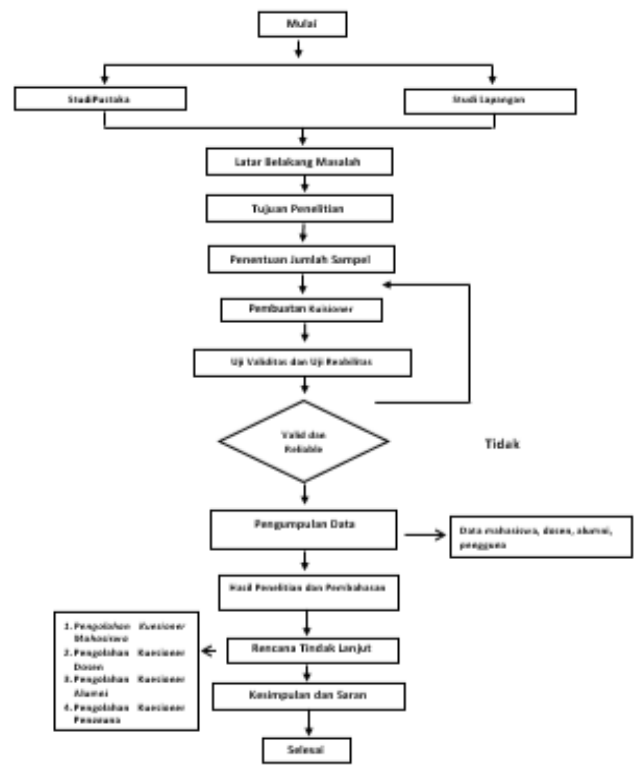

Gambar 1. Metodologi Penelitian 


\section{Hasil dan Pembahasan}

Dalam penelitian ini menyebar kuesioner 1 Kuesioner Umpan Balik Dosen Terhadap Proses Pembelajaran, Kompetensi Lulusan Menurut Pengguna.

Tabel 1.

Kuesioner Umpan Balik Dosen Terhadap Proses Pembelajaran, Kompetensi Lulusan Menurut Pengguna

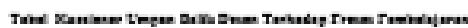

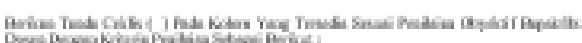

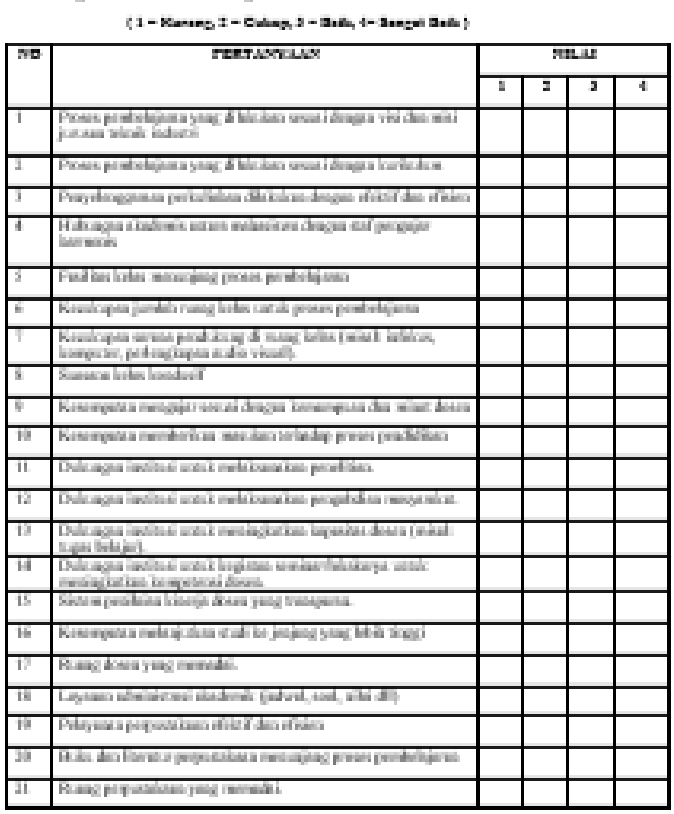

\subsection{Penentuan Jumlah Sampel}

Untuk menentukan jumlah sampel dilakukan dengan rumus Slovin. Diketahui jumlah populasi pengguna/mahasiswa aktif Teknik Industri UMJ tahun 2016-2017 sebesar 507 dan persen kelonggaran yang ditentukan sebesar $5 \%$.

Berdasarkan rumus Slovin maka minimal jumlah sampel yang dibutuhkan adalah :

$$
\begin{gathered}
n=\frac{N}{1+N \cdot e^{2}} \\
n=\frac{507}{1+507(0,05)^{2}} \\
n=224 \text { responden }
\end{gathered}
$$

\subsection{Pengujian Kuesioner}

Untuk menguji validitas dan reliabilitas dari instrumen yang digunakan dilakukan penyebaran kuesioner. Nilai koefisien korelasi yang didapatkan melalui perhitungan dari tiap butir pernyataan akan dibandingkan dengan nilai korelasi pada tabel Pearson Product Moment.
Apabila nilai koefisien korelasi hasil perhitungan lebih besar daripada nilai koefisien korelasi pada tabel, maka atribut pelayanan tersebut dinyatakan data valid. Dengan menggunakan tingkat signifikan 5\%. Maka nilai tabel Pearson Product Moment (r) adalah sebesar 0,361.

\subsubsection{Pengujian Reliabilitas}

Setelah melakukan pengujian validitas maka selanjutnya adalah pengujian reliabilitas, dilakukan dengan menggunakan metode internal consistency untuk mengetahui apakah instrument tersebut bisa digunakan beberapa kali untuk mengukur objek yang sama. Pengujian reliabilitas dilakukan dengan menghitung koefisien alpha cronbach. Pengujian ini dilakukan pada kuesioner dengan bantuan software SPSS

\subsubsection{Pengolahan Data Kuesioner Umpan Balik} Mahasiswa terhadap Proses Pembelajaran

Kuesioner umpan balik mahasiswa terhadap proses pembelajaran adalah kuesioner untuk menilai kualitas proses pembelajaran di Teknik Industri.

Tabel 2.

\begin{tabular}{|c|c|c|}
\hline No & PERTANYAAN & NILAI \\
\hline & SARANA DAN PRASARANA & \\
\hline 1 & Jumlah ruang kelas yang memadai untuk proses pembelajaran. & 2,4 \\
\hline 2 & Meja dan Kursi dalam kondisi baik dan tertata rapi. & 2,4 \\
\hline 3 & Kelengkapan dan kesiapan alat dalam proses belajar mengajar. & 2,4 \\
\hline 4 & Kebersihan, kerapian, dan kenyamanan ruang kelas. & 2,4 \\
\hline 5 & Laboratorium yang luas & 2,4 \\
\hline 6 & Ketersediaan softucare pengolah data terkait kegiatan praktikum & 2,4 \\
\hline 7 & Peralatan Lab yang lengkap & 2,4 \\
\hline 8 & $\begin{array}{l}\text { Tersedianya modul kuliah daan modul praktikum yang dapat } \\
\text { mendukung proses pembelajaran. }\end{array}$ & 2,4 \\
\hline 9 & Terdapat Toilet yang bersih. & 2,4 \\
\hline 10 & Ruang perpustakaan yang memadai. & 2,7 \\
\hline 11 & Koleksi buku/jumal ilmiah/e-book di perpustakaan yang memadai. & 2,5 \\
\hline 12 & Akses buku jumal ilmiah'e-book yang memadai. & 2,4 \\
\hline 13 & Kemudahan akses intemet (Akses wijf, SIKAD, kecepatan aksea) & 2,3 \\
\hline 14 & Penggunaan e-leaming untuk kegiatan pembelajaran. & 2,4 \\
\hline 15 & Kecukupan komputer dan perangkat teknologi informasi. & 2,3 \\
\hline 16 & Kecukupan sarama pendukung lainnya (olah raga, musik, dil). & 1,9 \\
\hline 17 & Kecukupan ruang terbuka hijau. & 1,7 \\
\hline 18 & Kecukupan ruang belajar mandiiri. & 1,9 \\
\hline 19 & Pelayanan kesehatan yang memadai & 1,9 \\
\hline \multirow[t]{2}{*}{20} & Tempat parkir yang luas dan aman. & 1,7 \\
\hline & $\begin{array}{l}\text { PELAYANAN PENDIDIKAN DAN PROSES } \\
\text { PEMBELAJARAN }\end{array}$ & \\
\hline
\end{tabular}

Hasil Pengolahan Kuesioner Umpan Balik Mahasiswa terhadap Proses Pembelajaran

Hasil Umpan Balik Mahasiswa terhadap Proses Pembelajaran setelah diurutkan dari nilai terendah untuk diberikan tindak lanjut oleh 
Program Studi sehingga dapat dilakukan langkah perbaikan untuk peningkatan kualitas proses pembelajaran.

Tabel 3.

Hasil Umpan Balik Dosen terhadap Proses Pembelajaran setelah diurutkan dari nilai terendah dan Tindak Lanjut Program Studi

\begin{tabular}{|c|c|c|}
\hline T & Kurang cukupnya suang iebouka hijau. & $\begin{array}{l}\text { Menambah tanaman hias diarea } \\
\text { kampus }\end{array}$ \\
\hline 2 & 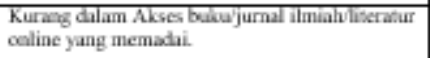 & $\begin{array}{l}\text { Betangganan jumal coline, } \\
\text { menambah koleksi c-book }\end{array}$ \\
\hline 3 & $\begin{array}{l}\text { Kurang cukup sarana pendukung di ruang leclas } \\
\text { (unikal: infoluse, kamputer, perlengkapas audio } \\
\text { visual). }\end{array}$ & $\begin{array}{l}\text { Menambah dan mempestaiki } \\
\text { alat penbelajaran }\end{array}$ \\
\hline 4 & Kectwopun alat-alat praktikum. & $\begin{array}{l}\text { Meng-upgrade peralatan } \\
\text { laboraborina }\end{array}$ \\
\hline 5 & $\begin{array}{l}\text { Dukungan tersologi informassi untuk membanfu } \\
\text { legiatan penbelajaran belum optimal }\end{array}$ & $\begin{array}{l}\text { Mengoptimalkan teknologi } \\
\text { infoemasi }\end{array}$ \\
\hline 6 & $\begin{array}{l}\text { Kurang cukup jumlah nuang helas untuk proses } \\
\text { pembelajara }\end{array}$ & $\begin{array}{l}\text { Membuat penjadtealan yang } \\
\text { serintegnasi }\end{array}$ \\
\hline 7 & $\begin{array}{l}\text { Koleksi bukwyunal/hiteratur di perpustakaan } \\
\text { yang kurang memadai. }\end{array}$ & $\begin{array}{l}\text { Menambah jumlah koleksi } \\
\text { buhajjumal/iteratur } \\
\text { diperpustakaan }\end{array}$ \\
\hline 8 & $\begin{array}{l}\text { Kurang cukup komputer dan perangkat tersologi } \\
\text { infoemasi lainaya. }\end{array}$ & Menambar jumlah komputer \\
\hline 9 & $\begin{array}{l}\text { Alat laboratocium lourang mesuajang proses } \\
\text { pembelajara }\end{array}$ & $\begin{array}{l}\text { Menambab peralatan } \\
\text { laboratorimen }\end{array}$ \\
\hline 10 & 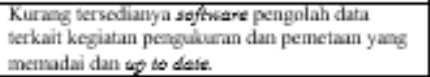 & Menamba software \\
\hline$\pi$ & $\begin{array}{l}\text { Pelayana perpustakian hurang efeltif dan } \\
\text { efisien }\end{array}$ & $\begin{array}{l}\text { Mengoptimalian pelayanan } \\
\text { perpustakaam dengan sistem } \\
\text { infoemasi databuse }\end{array}$ \\
\hline
\end{tabular}

\subsubsection{Pengolahan Data Kuesioner Alumni}

Kuesioner Alumni adalah kuesioner untuk mengetahui waktu tunggu mendapatkan pekerjaan dan bidang keahlian alumni Teknik Industri.

Rekapitulasi persentase kesesuaian bidang keahlian $=38 / 43 \times 100=88,37 \%$

Rekapitulasi rata-rata masa tunggu kerja $=80$ bulan $/ 43$ x $100=1,9$ bulan

Rencana Tindak lanjut Program studi :

1. Mensosilaisasikan lapangan kerja yang sesuai dengan bidang Teknik Industri melalui jobfair

2. Membuat kerjasama dgn perusahaan yg dpt memberikan kesempatan lapangan kerja untuk mahasiswa

\subsubsection{Pengolahan Data Kuesioner Kompetensi Lulusan Menurut Pengguna}

Kuesioner Kompetensi Lulusan menurut Pengguna adalah kuesioner untuk menilai kualitas lulusan Teknik Industri di Dunia Kerja.

Tabel 4.

Hasil Pengolahan Kuesioner Kompetensi Lulusan Menurut Pengguna

\begin{tabular}{|c|c|c|c|c|c|}
\hline \multirow{3}{*}{ No } & \multirow{3}{*}{ Jenis Kemampuan } & \multicolumn{4}{|c|}{ Tanggapan Pihak Pengguna } \\
\hline & & $\begin{array}{c}\text { Sangat } \\
\text { Baik }\end{array}$ & Baik & Cukup & Kurang \\
\hline & & $(\%)$ & $(\%)$ & $(\%)$ & $(\%)$ \\
\hline 1 & $\begin{array}{l}\text { Integritas (etika dan } \\
\text { moral) }\end{array}$ & 48 & 52 & - & - \\
\hline 2 & $\begin{array}{l}\text { Keahlian berdasarkan } \\
\text { bidang ilmu } \\
\text { (profesionalisme) }\end{array}$ & 35 & 65 & - & - \\
\hline 3 & Bahasa Inggris & 1 & 63 & 35 & 1 \\
\hline 4 & $\begin{array}{l}\text { Penggunaan Teknologi } \\
\text { Informasi }\end{array}$ & 32 & 60 & 8 & - \\
\hline 5 & Komunikasi & 43 & 57 & - & - \\
\hline 6 & Kerjasama tim & 53 & 44 & 3 & - \\
\hline 7 & Pengembangan diri & 33 & 63 & 4 & - \\
\hline & Total & $(245)$ & (404) & $(50)$ & (1) \\
\hline
\end{tabular}

Hasil Umpan Balik dari Pihak Pengguna dapat dijadikan tolak ukur oleh Program Studi untuk dilakukan rencana tindak lanjut sehingga dapat menghasilkan lulusan yang berkompetensi dan mampu berdaya saing di dunia kerja.

\section{Simpulan}

Umpan balik dari mahasiswa, dosen, alumni dan pengguna lulusan mengenai proses pembelajaran di Jurusan Industri FT UMJ.

a. Umpan balik mahasiswa terhadap proses pembelajaran.

Pelayanan pendidikan dan proses pembelajaran adalah bimbingan Bimbingan dan konseling yang dilakukan secara periodik belum optimal, Petugas / karyawan tidak memberi info yang jelas dan mudah untuk dimengerti. Pemberian beasiswa terhadap mahasiswa berprestasi belum optimal.

b. Umpan balik dosen terhadap proses pembelajaran Kurang cukupnya ruang terbuka hijau. Kurang dalam Akses buku/jurnal ilmiah/literatur online yang memadai. Pelayanan perpustakaan kurang efektif dan efisien.

c. Umpan balik Alumni.

Rekapitulasi persentase kesesuaian bidang keahlian $=38 / 43 \times 100=88,37 \%$ 
Rekapitulasi rata-rata masa tunggu kerja = 80 bulan $/ 43 \times 100=1,9$ bulan

d. Umpan balik mengenai tanggapan pihak pengguna mengenai :

1) Integritas : sangat baik $48 \%$, baik $52 \%$

2) Keahlian berdasarkan bidang ilmu (profesionalisme) : sangat baik $35 \%$, baik $65 \%$

3) Bahasa inggris : sangat baik $1 \%$, baik $63 \%$, cukup $35 \%$, kurang $1 \%$

4) Penggunaan teknologi informasi : sangat baik $32 \%$, baik $60 \%$, cukup $8 \%$

5) Komunikasi : sangat baik $43 \%$, baik $57 \%$

6) Kerjasama tim : sangat baik $53 \%$, baik $44 \%$, cukup $3 \%$

7) Pengembangan diri : sangat baik $33 \%$, baik $63 \%$, cukup $4 \%$

\section{Daftar Pustaka}

Ariani, Dorothea Wahyu. Manajemen Kualitas. Universitas Atmajaya Yogyakarta, 1999.

Aritonang, Lerbin. Kepuasan Pelanggan, Pengukuran dengan SPSS. Penerbit PT Gramedia Jakarta, 2005.

Fandy Tjiptono. Service Management, Penerbit ANDI Yogyakarta, 2012

Gaspersz, Vinscent. Statiscal Process control dalam manajemen bisnis total. Penerbit PT Gramedia Pustaka Utama Jakarta, 1998.

Sugiyono. Metode Penelitian Administrasi. CV alfa beta bandung, 1998 .

Tjiptono, Fandy. Total Quality Service. Penerbit Andi Yogyakarta, 1997.

Yamit, Zulian. Manajemen Kualitas Produk dan Jasa. Penerbit Ekonisia Yogyakarta, 2001.

Service Quality dan Satisfaction (Servqual). Fandy Tjiptono, Ph.D. Penerbit ANDI. Yogyakarta. 